\title{
EFFECTS OF NITROGENOUS FERTILIZERS ON SEED GERMINATION OF OROBANCHE SOLMSII C.D. CLARKE
}

\author{
Anjana Bista \\ Department of Botany, Amrit Campus, Lainchaur, Kathmandu
}

\begin{abstract}
Seven nutrient chemicals were tested in vitro during pre- and post- conditioning period in order to know their effects on $O$. solmsii seed germination. All the concentrations $(4,8$ and $16 \mathrm{mM})$ of nutrient applied during pre-conditioning period inhibited germination, whereas the effects of chemicals applied during post-conditioning period was either inhibitory or ineffective depending upon the nutrients. Ammonium nitrate and ammonium chloride was effective in reducing seed germination by $43 \%$ and $41 \%$, respectively, and were more than any other ammonium salts. This study showed that all forms of nitrogen are not equally effective in reducing of germination.
\end{abstract}

Key words: Broomrape, pre-conditioning, post-conditioning.

\section{INTRODUCTION}

Orobanche species, commonly called broomrapes, are exclusively obligate root parasites, infecting a wide variety of dicotyledonous plants. The most common host of Orobanche species in Nepal are tori (Brassica campestris var. toria L.), tobacco (Nicotiana tabacum L.) and broad leaf mustard (Brassica juncea Coss.). They depend totally upon host plants for their nutritional requirements and suck nutrients by means of haustoria. Initial attempts to reduce broomrape seed banks using the synthetic Strigolactone were made by using synthetic Strigolactone analogue GR7 (Fernandez-Aparicio et al. 2011). However, field application of these GR type Strigolactones were unable to control the parasite.

Many workers have observed that the parasite prefer nutritionally poor soil and are suppressed in sufficiently fertilized soil. The percentage of broomrape seed germination was decreased with increase of nitrogenous fertilizer. Habimana et al. (2014) reported that high level of nitrogen fertilizer suppresses Orobanche growth and increases crop yield. Fertilizers might have a direct effect at the early stages of development. Such an observation might indicate that the suppression of Orobanche plants in fertilized fields is mainly due to the suppression of seed germination, rather than via host. Therefore, in this study different nutrient chemicals were tested to know their effects on seed germination which might help to understand the intensity of infestation in response to different nutrients chemicals.

\section{MATERIALS AND METHODS}

Altogether seven nutrients (potassium nitrate, sodium nitrate, calcium nitrate, ammonium chloride, ammonium sulphate, ammonium nitrate 
and urea) were tested for their effects on seed germination. In the first set of experiment, the seeds were pre-conditioned in water for 10 days in dark at $20^{\circ} \mathrm{C}$ and post-conditioned with different concentrations $(4,8$ and $16 \mathrm{mM})$ of nutrient chemicals. While pre-conditioning, seeds were surface sterilized by $1 \%$ sodium hypochlorite solution. After 10 days, seeds were postconditioned with the nutrient chemicals together with the solution of $\mathrm{GR}_{24}$ (growth regulator) and incubated at $25^{\circ} \mathrm{C}$. In the second set of experiment, Sterilized Orobanche seeds were pre-conditioned in different concentrations (4, 8 and $16 \mathrm{mM})$ of nutrient chemicals at $20^{\circ} \mathrm{C}$ in dark. After 10 days, seeds were post-conditioned with $\mathrm{GR}_{24}$ at $25^{\circ} \mathrm{C}$ in dark condition.

In both the experiments, post-conditioning was done in petridishes each containing 10 GFFP disks lying over Whatman filter paper. There were about 40-45 seeds per disk. $\mathrm{pH}$ of the test solution including distill water were maintained at 6.5. Percentage of seed germination was recorded by stereomicroscope after two weeks of incubation. There were three replications for each subtreatment and the petri-dish with $\mathrm{GR}_{24}$ alone was taken to be control.

\section{Data analysis}

The seed germination data obtained from experiments were processed through ANOVA and Duncan's Multiple Range Test (DMRT) to understand difference between the values of germination of Orobanche seeds resulted from different treatments.

\section{RESULTS AND DISCUSSION}

All the concentrations $(4,8$ and $16 \mathrm{mM})$ of nutrient chemicals applied during pre-conditioning period inhibited seed germination of $O$. solmsii while the chemicals when applied during postconditioning period were either inhibitory or ineffective depending upon the nutrient chemicals.
Ammonium nitrate was highly (43\%) effective in reducing the seed germination (Table 1). The reduction increases in seed germination with the increase of concentration of the chemical was $57.34 \%$ at $16 \mathrm{mM}$. (Fig. 1). The inhibitory performance of ammonium nitrate in vitro studies explains why the chemicals applied in Orobanche infested fields suppresses the emergence of Orobanche plants as reported by Kukula and Masri (1984), Jain and Foy (1987, 1992), Dermirkan and Nemli (1994) and Khattri (1997).

Table 1. Decreasing order of nutrient chemicals based on their overall inhibitory effects on germination of $O$. solmsii seeds.

\begin{tabular}{lc} 
Nitrogenous chemicals & $\begin{array}{c}\text { Inhibition of seed } \\
\text { germination (\%) }\end{array}$ \\
\hline Ammonium nitrate & 43 \\
Ammonium chloride & 41 \\
Ammonium sulphate & 35 \\
Urea & 26 \\
Potassium nitrate & 25 \\
Sodium nitrate & 15 \\
Calcium nitrate & 7 \\
\hline
\end{tabular}

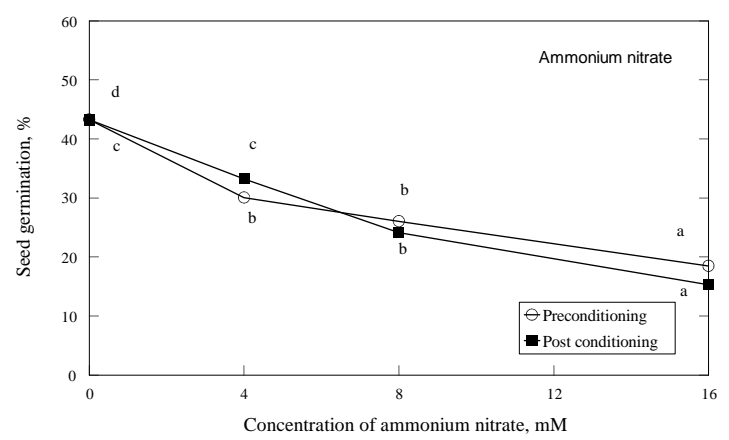

Fig. 1. Effects of ammonium nitrate on germination of $O$. solmsii seed.

(Treatment values having same letters do not differ significantly at $\mathrm{P}=0.05$ according to Duncan's Multiple Range Test; The statistical notations apply to the following figures related to effects of nutrients on Orobanche seed germination) 
Similarly, all the concentrations of ammonium sulphate reduced germination when applied during pre-conditioning period but the reduction in postconditioning period was markedly lower than that of pre-conditioning period in the same concentration (Fig. 2). Pieterse (1989), Jain and Foy (1992) and van Hezewijk and Verkleij (1996) have also arrived to similar conclusion in $O$. aegyptiaca and $O$. crenata. The inhibitory effect of ammonium sulphate was also evident in greenhouse and field conditions. Abu-Irmaileh $(1979,1981)$ was able to obtain good suppression of $O$. ramosa in tomato and tobacco with ammonium sulphate at $4 \mathrm{~g} / \mathrm{kg}$ of soil. Van Hezewijk et al. (1991) demonstrated significant reduction of $O$. crenata in broad bean following application of ammonium sulphate to 14 and $28 \mathrm{~kg}$ $\mathrm{N} / \mathrm{ha}$. An increased ammonium supply generally reduces the uptake of potassium (Welte and Wererner 1962) and may affect the osmotic balance of Orobanche.

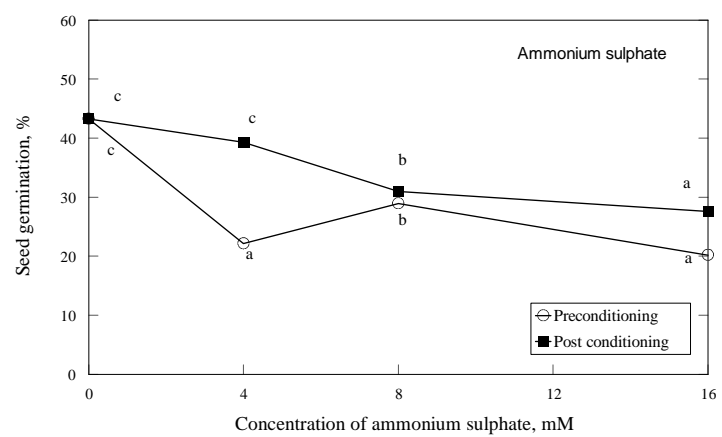

Fig. 2. Effects of ammonium sulphate on $O$. solmsii seed germination.

When seed germination values in different concentrations of each nutrient chemical were averaged, ammonium nitrate appeared most effective in stimulating and calcium nitrate in reducing the germination of the parasite (Table 1).

Ammonium chloride reduced seed germination when applied during pre-conditioning period. The reduction was highest at $4 \mathrm{mM}$ and lowest at 16 $\mathrm{mM}$ (Fig. 3). The post-conditioning effects showed significant reduction only at $16 \mathrm{mM}$. The result agrees with Westwood (1995) who reported that the chemical caused a high inhibition of seed germination in O. aegyptiaca and O. ramosa.

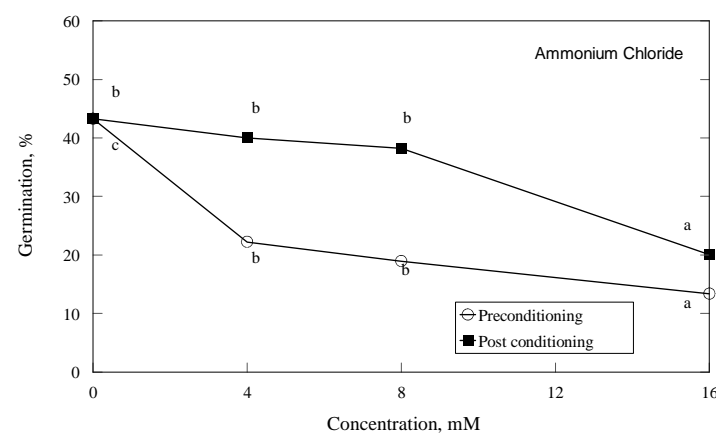

Fig. 3. Effects of ammonium chloride on $O$. solmsii seed germination.

Calcium nitrate significantly reduced seed germination ( $8 \mathrm{mM}, 16 \mathrm{mM})$ when applied during pre-conditioning period (Fig. 4). Calcium nitrates and sodium nitrate proved less effective than potassium nitrate (Table 1) in inhibiting the seed germination. Sodium nitrate showed significant reduction during pre and post-conditioning period at $8 \mathrm{mM}$ and $16 \mathrm{mM}$ but ineffective at $4 \mathrm{mM}$ concentration (Fig. 5). The trend of reduction was more or less similar and the reduction was up to $35 \%$. This is partially in agreement with the findings of Jain and Foy (1987) who found sodium nitrate to be ineffective in $O$. aegyptiaca.

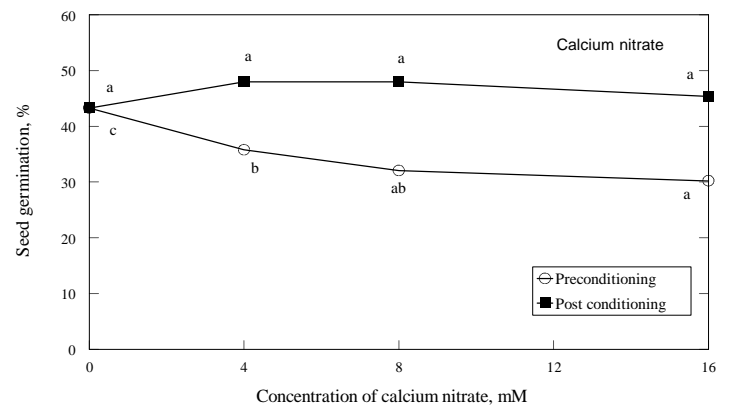

Fig. 4. Effect of calcium nitrate on $O$. solmsii seed germination. 


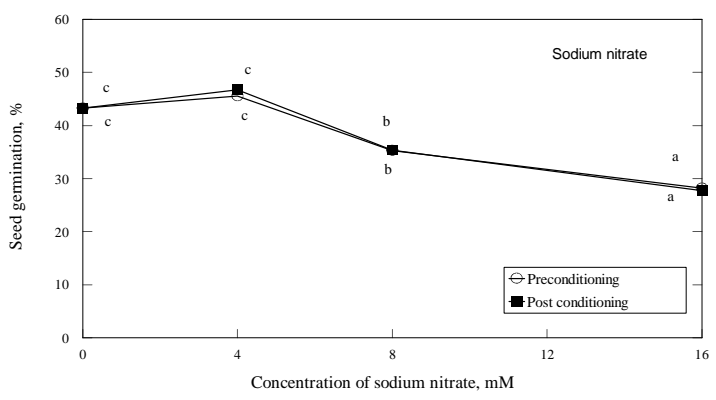

Fig. 5. Effect of sodium nitrate on $O$. solmsii seed germination.

Potassium nitrate applied during preconditioning period invariably reduced seed germination up to $42.75 \%$ (Table 1) as compared to control (Fig. 6), while the application of potassium nitrate during the post-conditioning period did not affect seed germination significantly. Regarding the effect of potassium nitrate, there are contradictory reports. Van Hezewijk et al. (1996) found no effect of potassium nitrate on the germination of $O$. crenata seeds. Similarly, Linke (1987) did not observe any effect of potassium nitrate on $O$. ramosa. In contrast to the results of previous workers, in our study, potassium nitrate inhibited germination of O. solmsii seeds.

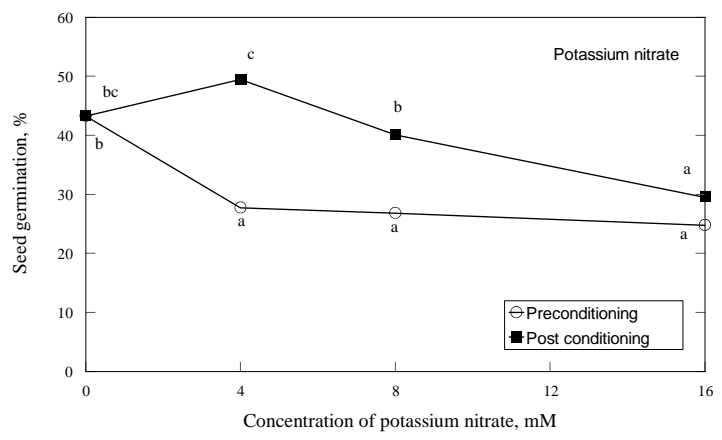

Fig. 6. Effect of potassium nitrate on $O$. solmsii seed germination.

Like other nitrogenous nutrients, urea was also found to reduce $O$. solmsii seed germination but reduction was more effective at $16 \mathrm{mM}$ (Fig. 7). The inhibition of seed germination by urea was also associated with the development of thick and short germ tubes. These results support the findings of Linke (1987) and Van Hezijk and Verkleij (1996) who observed significant reduction of seed germination by urea in $O$. crenata and $O$. ramosa.

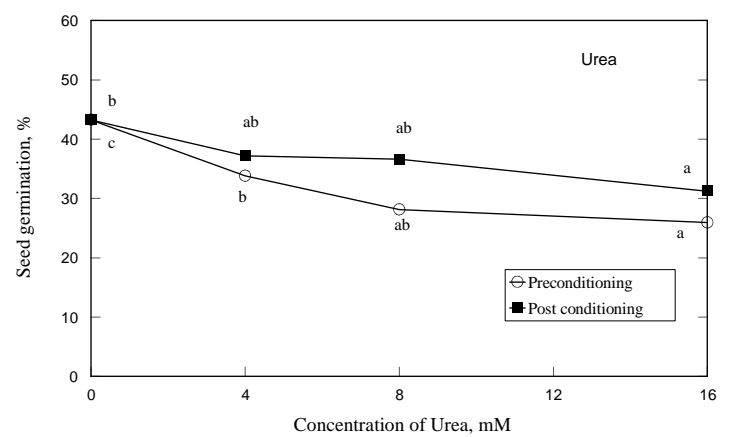

Fig. 7. Effects of urea on $O$. solmsii seed germination.

The present study supports the views of AbuIrmaileh (1981), Press and Stewart, 1986, McNally and Stewart (1987) that all forms of nitrogen are not equally effective in reducing Orobanche seed germination (Table 1). The additional outcome of the present study is that the inhibitory effect is more pronounced when the chemicals are applied during pre-conditioning period compared to their application during post-conditioning period; and the ammonium forms of nitrogen inhibit more than the nitrate forms, while urea has an intermediate effect.

It is obvious that nutrient chemicals present in soil or water are of any help to the germinating seeds. In case of Orobanche species, seeds require chemical stimulant(s) for the onset of germination apart from favorable climatic conditions. In this context, it could be assumed that nitrogenous fertilizers applied during seed germination period either inactivate stimulatory molecules necessary for Orobanche seed germination or upset required osmotic difference between soil solution and sap of seed cells and thereby intake of stimulants by seeds is decreased or play antagonistic role in the biosynthesis of $\mathrm{GA}_{3}$ which are prerequisite for any seed germination. The last point of assumption seems more appealing because it tends to explain

ECOPRINT VOL 21，2014 
why nutrient chemicals applied during preconditioning period has more inhibitory effects than applied during post conditioning period.

\section{REFERENCES}

Abu-Irmaileh, B.E. 1979. Effects of various fertilizers on broomrape (Orobanche ramosa) infestation of tomatoes. In: Proceedings of $2^{\text {nd }}$ International Symposium, Parasitic Weeds. (eds.) Musselman, L.J., A.D. Worsham and R.E. Eplee, (eds.). Raleigh, USA. North Carolina State University, pp. 278-284.

Abu-Irmaileh, B.E. 1981. Response of hemp broomrape (Orobanche ramosa) infestation to some nitrogenous compounds. Weed Science 29:8-10.

Demirkan, H. and Y. Nemli. 1994. Effects of some fertilizers on Orobanche ramosa L. on tomato. In: Biology and Management of Orobanche, Proceedings of $3^{\text {rd }}$ International Workshop on Orobanche and Related Striga Research. (eds.) Pieterse, A.N., J.A.C. Verkleij and S.J. TerBirg. Royal Tropical Institute, Amsterdam, The Netherlands, pp. 449-501.

Fernández-Aparicio, M., K. Yoneyama and D. Rubiales. 2011. The role of strigolactones in host specificity of Orobanche and Phelipanche seed germination. Seed Sci. Res. 21(1):55-61.

Foy, C.L., R. Jain and R. Jacobsohn. 1989. Recent approach for chemical control of broomrape (Orobanche spp.) Rev. Weed Science 4:123152.

Habimana, S., A. Nauwumuremyi and J.D. Chinama. 2014. Management of Orobanche in field crops- A review. Journal of Soil Science and Plant Nutrition 14(1):43-62.

Jain, R. and C.L. Foy (1987). Influence of various nutrients and growth regulators on germination and parasitism of Orobanche aegyptiaca Pers. seeds. In: Proceedings of $4^{\text {th }}$ ISPFP, Marburg. (eds.) Chr. Weber, H. and W. Forstreuter. pp. 427-436.

Jain, R. and C.L. Foy. 1992. Nutrient effects on parasitism and germination of Egyptian broomrape (Orobanche aegyptiaca). Weed Technol. 6:269-275.

Khattri, G.B. 1997. Some Studies on Biology and Control of Orobanche in Brassica Crops. A thesis submitted for the degree of doctor of philosophy in Botany to the B.R.A. Bihar University, Muzaffarpur, India. 157 pp.

Kukula, S. and K.H. Masri. 1984. Integrated cultural practices and chemical control of Orobanche crenata in fava bean. In: Proceedings of Third International Symposium in Parasitic Weeds. (eds.) Parker, C., L.J. Musselman, R.M. Poihill and A.K. Wilson. ICARDA, Aleppo, Syria. pp. 256-261.

Linke, K.H. 1987. Untersuchungenuberkeimung und Jugedentwicklung von Striga and Orobanche Weikersheim, FRG:verlag Josef Margraf. 95 p.

McNally, S.F. and G.R. Stewart. 1987. Inorganic nitrogen assimilation by parasitic angiosperms. In: Proceedings of fourth International symposium in Parasitic Flowering Plants. (eds.) Weber, H.C. and W. Forstreuter.. Marburg, Germany:Phillipps-Universitat, pp. 539-546.

Pieterse, A.H. 1989. The effects of nitrogen fertilizers on the germination of seeds Striga hermothica and Orobanche crenata. In: Proceedings of the International Worshop on Orobanche Research. FRG, pp. 115-123.

Press, M., C. Shah and G.R. Stewart. 1986. The parasitic habit: trends in metabolic reductionism. In: Biology and Control of Orobanche. (ed.) S. ter Borg. LH/VPO, Wageningen, pp. 96-106. 
Van Hezewijk, M.J. and J.A.C. Verkleij. 1996. The effect of nitrogenous compounds on in vitro germination of Orobanche crenata Forsk. Weed Res. 3c:395-404.

Vaz Hezewijk, M.J, J.A.C. Verkleij and Pieterse. 1991. The effects of ammonium fertilizer in combination with nitrification inhibitors on Orobanche crenata infestation in faba. In: Proceedings of Fifth International Symposium on Parasitic Weeds. (eds.) Ransom, J.K., L.J. Musselman, A.D. Worsham and C. Parker. CIMMYAT, Nairobi, Kenya. pp. 440-480.
Welte, E. and W. Werner. 1962. IonenAustauschversucheuber die Beeinflussung der Kationenaufnahme der Pflanzendurch die Stickstoff-Form. Agrochim.

Westwood, J.H. 1995. cited in V.K. Nandula, 1998, Selective control of Egyptian broomrape (Orobanche aegyptiaca Pers.) by glyphosphate and its amino acid status in relation to selected host. Ph.D. Thesis. Virginia Polytechnic Institute and State University, Blackburg, Virginia 